\title{
Dorota Furtak-Masica
}

SWPS, Warszawa

\section{Przyczynek do poszukiwań performatyki we współczesnych praktykach politycznych}

Abstrakt: Dziś, jak przekonuje McKenzie, każda niemal sfera życia podlega swoistemu nakazowi performowania. Analiza praktyk politycznych (współczesnych i minionych) za pomocą narzędzi oferowanych przez performatykę staje się w tym kontekście oczywista. Performatyka nie jest jednak, jak wiadomo, orientacją jednorodną. Przedstawię więc najpierw argumenty, które skłoniły mnie do wyboru tego jej nurtu, który eksponuje teatralną genealogię dzisiejszych performansów kulturowych i organizacyjnych (o teatralizacji polityki mówił już Bertolt Brecht). Jestem przekonana, że narzędzia badawcze oferowane przez ów nurt najlepiej pozwalają opisać strategie stosowane dziś zarówno w polityce, jak i polityczności. Poczynione wstępnie ustalenia teoretyczne postaram się ,przetestować” na przekładach z polskich praktyk politycznych.

Słowa klucze: performatyka, teatr, polityka

Nie lekceważmy teatru — nawoływał Zygmunt Hübner. Tkwi bowiem w nim niezwykła siła, często zapominamy, że jest on „szekspirowskim zwierciadłem świata, jak i soczewką skupiającą promienie wielu słońc. Soczewka może zawsze spowodować pożar"l. Wydawać by się mogło, że w epoce dominującej kultury mass mediów sztuka ta staje się coraz mniej istotna. Tymczasem, napomina Hübner, teatr może być miejscem istotnych rozgrywek o dużym zasięgu. Nie bez powodu chciałam cytowane zdanie połączyć z wezwaniem McKenziego „Performuj albo...", które w polityce działa w sposób oczywisty. Niewiele osób zdaje się wyciągać z analizy performatywnej praktyk politycznych głębsze wnioski niż tylko „piarowskie”2. Jak przekonuje Dariusz Kosiński, taka analiza wymaga rozległego spojrzenia z uwzględnieniem wielowarstwowości kreacji artystycznych. Zastosowanie więc analizy performatywnej do badania współczesnych praktyk politycznych, ze szczególnym uwzględnieniem narzędzi teatralnych, wydaje mi się bezdyskusyjne.

${ }^{1}$ Z. Hübner, Polityka i teatr, Warszawa 2009, s. 12.

2 D. Kosiński, Teatra polskie. Rok katastrofy, Warszawa-Kraków 2013, s. 64. 
Performatyka zaczyna się tam, gdzie większość dyscyplin się kończy. Znaczy to, że nie bada ona konkretnego wytworu sztuki czy kultury, skupia się natomiast na grze związków i relacji. W takim kontekście należy więc moim zdaniem badać współczesne praktyki polityczne, które uwalniając się od historycznego ceremoniału i rytuału, stały się formami otwartymi, występującymi w konkretnej przestrzeni.

Performatyka pozwala na użycie narzędzi przypisanych różnym dziedzinom, co daje możliwość osadzenia praktyk politycznych w kulturowym kontekście i pozwala na swego rodzaju analizę kulturową.

W swoich rozważaniach na temat miejsca, jakie zajmuje performatyka w działaniach politycznych, chciałabym głównie odwołać się do definicji „widowiska” $\mathrm{i}$, ,inscenizacji”. Widowisko, zdaniem niektórych badaczy, jest dość niefortunnym określeniem. Na przykład Tomasz Kubikowski podkreśla, że „widowisko ujmuje zjawiska w aspekcie jego biernej percepcji, a nie w kluczowym dla performansu aspekcie działania"3. Uważam, powołując się na Dariusza Kosińskiego, że lepiej wykorzystywać słowo „widowisko” niż obco brzmiące „performans”. Pisze on: „Performance i performatyka są obce, ale przez to nieoczywiste, nie ograniczają myślenia już u samych jego początków [...]. Performatyka będzie tym, co polscy badacze postanowią z nią zrobić" 4 .

Punktem odniesienia w moich rozważaniach będą definicje widowiska i inscenizacji Patrice Pavisa i Eriki Fischer-Lichte. Terminy te kojarzone są głównie $\mathrm{z}$ badaniami nad teatrem. Elementów teatralnych nie brakuje w stosowanych praktykach politycznych, dla których różni badacze proponują rozmaite nazwy. Obecnie mówi się o ich teatralizacji, estetyzacji polityki, poppolityce, politainmencie (komercjalizacji komunikacji społecznej) czy działaniach performatywnych właśnie.

Chcąc uwzględnić wspomniane narzędzia teatralne, połączyć należy współczesne działania polityczne także z założeniami teatru postdramatycznego H.T. Lehmana, z których wynika, że widowiska polityczne powinniśmy traktować dzisiaj jako inscenizacje. Taka potrzeba spojrzenia wynika nie tylko z oczywistych związków między teatrem a zachowaniami politycznymi, lecz także z współczesnych przemian kulturowych. Ogromny wpływ mają bowiem na nie media, które dyktując politycznym aktorom warunki medialnego „istnienia”, wpływają na kształt ich występów oraz określają formę uczestnictwa.

Największą rolę odgrywa w tym aspekcie zwłaszcza telewizja, która jak pisał Bourdieu: „wykorzystuje dramaturgię w podwójnym sensie tego słowa: reżyseruje wydarzenia (inscenizuje je w obrazach) oraz wyolbrzymia znaczenie (nadaje mu charakter dramatu i tragedii)" "5. Telewizyjne przekazy polityczne znajdują się mię-

${ }^{3}$ T. Kubikowki, Wstęp, [w:] J. McKenzie, ,Performuj albo...” Od dyscypliny do performansu, przeł. T. Kubikowski, Kraków 2011.

${ }^{4}$ D. Kosiński, Tratwa i cuma, ,Didaskalia” 2007, nr 77.

5 P. Bourdieu, O telewizji. Panowanie dziennikarstwa, przeł. K. Sztander-Sztanderska, A. Ziółkowska, Warszawa 2009, s. 44. 
dzy informacją a rozrywką, przy czym ich prezentacja powinna się odbywać w taki sposób, aby widz długo po wyłączeniu odbiornika telewizyjnego nie mógł o nich zapomnieć.

Elementami charakterystycznymi inscenizacji są: obecność, nieprzewidywalność (sposoby zachowania się i wydarzenia), element budzenia uwagi i kierowania nią, okrojenie dialogu i zastąpienie go formą monologu, przygotowanie, konieczność posiadania szczególnych umiejętności. Zbigniew Raszewski, pisząc o widowisku, włącza w nie także ryzyko związane $\mathrm{z}$ apelowaniem o uwagę innych ${ }^{6}$.

Pojęcie inscenizacji jest przy okazji rozważanego tematu niezwykle istotne. Przełom lat 60. i 70. to zmiana w rozumieniu inscenizacji, gdyż praktyki performansu i happeningu odrzucają inscenizatora, traktując inscenizację jak dzieło otwarte. Lata późniejsze przynoszą coraz bardziej płynne pojęcie inscenizacji, które zaczyna rywalizować z pojęciem performans. To zbliżenie performansu i inscenizacji stało się korzystne dla obu, ponieważ ciągle zwiększające zakres swojego zainteresowania performance studies „odnalazły zagubioną dokładność i ponownie sięgnęły po narzędzia jeszcze niedawno uważane za archaiczne"7. Pavis sugeruje nawet, że powinno się stworzyć nowe pojęcia-worki, na przykład in p er for m a ty z a cj a, głównie dlatego że nie można dzisiaj stworzyć inscenizacji bez refleksji nad performance theory ani też performansu, którego nie dałoby się poddać analizie semiologicznej i fenomenologicznej.

Dla dziedzin takich jak teatrologia i kulturoznawstwo forma inscenizacji jest niezwykle ważna, ponieważ zjawiska współczesnej kultury dostarczają nam rozmaitych możliwości do posługiwania się inscenizacją. W przypadku badania zachowań politycznych pozwala to na odnowienie praktyk teatralnych. Prowadzić ma do tego analiza i zrozumienie odpowiednich momentów w historii teatru przy uwzględnieniu nowych odkryć teatralnych i działan kulturalnych. W obrębie działań politycznych z kolei sięganie po nowatorskie formy przekazu skutecznie współgra z marketingiem politycznym, który traktując owe formy jako produkty do sprzedaży, chce uczynić je bardziej atrakcyjne, dbając o użycie właściwych środków. Niewątpliwie wpływa to na estetyzację polityki, co najbardziej widoczne jest podczas kampanii wyborczych.

Jak pisze Erika Fischer-Lichte, mamy dzisiaj do czynienia z pewnego rodzaju zaczarowaniem polityki.

Obecność ludzi i przedmiotów tu i teraz powoduje, że świat staje się zaczarowany, a owo zaczarowanie jest także wyzwoleniem od obligacji rozumienia, ujawnieniem właściwego rozumienia ludzi i rzeczy ${ }^{8}$.

${ }^{6}$ Z. Raszewski, Teatr w świecie widowisk, Warszawa 1991, s. 35.

${ }^{7}$ P. Pavis, Współczesna inscenizacja, przeł. P. Olkusz, Warszawa 2011, s. 27.

${ }^{8}$ E. Fischer-Lichte, Estetyka performatywności, przeł. M. Borowski, M. Sugiera, Kraków 2008, s. 298. 
W przypadku odbioru przekazów politycznych należy pamiętać o ,efekcie wywołanym". Pojęcie to teatrologia niemiecka łączy z estetyką. Podczas wydarzenia inscenizacyjnego dochodzi do ruchów i oddziaływań między sceną a widownią. Wywołany efekt jest więc reakcją zwrotną na działania sceniczne. Produkcja takiego wydarzenia musi przewidywać efekty, jakie ono wywoła, musi wyobrazić sobie to, co widz zrozumie z założeń inscenizacyjnych.

Co więc znaczy inscenizować? Pobudzać i podtrzymywać zainteresowanie widza, zaszczepiać w nim pragnienie zobaczenia i zrozumienia. Erika Fischer-Lichte wskazuje na konieczność zaistnienia w przedstawieniu czynnika przyciągającego uwagę:

Sztuka przedstawienia w najbardziej oczywisty sposób na tym widać polega, żeby wszystko, co się w nim pojawia, uczynić godnym uwagi. A skoro wszystko, co się w nim pojawia, równie trudno przewidzieć, to wydaje się ono tyleż zaskakujące, co godne uwagi ${ }^{9}$.

Najlepszym, moim zdaniem, przykładem takich praktyk są polityczne widowiska Janusza Palikota, będące wynikiem jego działalności w latach 2008-2012, kiedy to szokował swoimi performansami, użytymi rekwizytami i cyniczną argumentacją polityczną. Propagując postawę kynika, obnażył dotychczasową „kulturę polityczną", tkwiącą w skostniałych ideałach i sztywnej formie ${ }^{10}$. Palikot dokonał rzeczy niezwykle istotnej, zwrócił bowiem uwagę na ujawnienie rzeczywistego, dynamicznego przebiegu niektórych zjawisk społeczno-politycznych. Oczywiście, to ujawnienie było działaniem wymierzonym przeciwko politycznym rywalom i miało za zadanie zdemaskowanie pewnych faktów, przypominając chociażby sprawę gwałtu dokonanego na kobiecie w komendzie policji w Lublinie. Stosując dialektykę pozbywania zahamowań - tak dobrze opisaną przez Sloterdijka, wpłynął na powstanie klimatu satyrycznego luzu, zyskując tym samym miano politycznego błazna. Jego praktyki polityczne $\mathrm{z}$ tego okresu, to dobrze zorganizowane inscenizacje, często przyjmujące formę ,totalnego widowiska", rozumianego jako rodzaj spektaklu oddziaływującego na wszystkie zmysły odbiorcy ${ }^{11}$. Tak było w przypadku happeningu w Kozłówce, gdzie pracę doktorską Lecha Kaczyńskiego czytało kilku zatrudnionych aktorów. Aktorzy wystąpili w przebraniach i w odpowiedniej scenografii, widowisko zaś dopełniali zatrudnieni liczni statyści. Całość stylizowana była na uroczysty komunistyczny pochód z odczytami Marksa, Engelsa i Lenina. Były więc białe bluzki i czerwone chusty, flagi, sztandary, pieśni komunistyczne i recytacje.

Janusz Palikot potrafił doskonale wykorzystać element zaskoczenia. Po pierwsze, my, jako widzowie, nie jesteśmy przyzwyczajeni do wyreżyserowanych spektakli politycznych, ponieważ polityka jawi nam się jako zbiór zasad i reguł. A to, co przedstawił Palikot, stoi w opozycji do takiego jej rozumienia, gdyż jest

\footnotetext{
${ }^{9}$ Ibidem, s. 268.

${ }^{10}$ P. Sloterdijk, Krytyka cynicznego rozumu, przeł. P. Dehnel, Wrocław 2008.

11 P. Pavis, Stownik terminów teatralnych, przeł. S. Świontek, Wrocław 2002.
} 
działaniem zupełnie pozbawionym klasycznych kanonów politycznych. Po drugie, element zaskoczenia w działaniach Palikota ma wywołać szok, staje się celem zdarzenia. Wymachiwanie gumowym penisem czy demonstracyjne picie alkoholu przed kamerami w europejskiej świadomości jest szokujące, ponieważ burzy tradycyjny obraz polityka. Szok i perwersja powodują zamazywanie tego, co tradycyjne, uznane i prawidłowe.

Na kształt jego perfomansów wpłynęła także forma popularnych gatunków rozrywkowych, a najistotniejsza wydaje się tu zasada numerów, doskonale opisana przez Lehmana w Teatrze postdramatycznym ${ }^{12}$. Rozwój kultury, w szczególności filmu i kina, uczynił z zasady numerów, epizodyczności i kalejdoskopowości zasadę naczelną. Przydatne wydaje się tu być odwołanie do formy kabaretu i variétés, opierających się na zasadzie parabazy, wyjściu aktora z roli i zwrócenia się do publiczności ${ }^{13}$. Kabaret korzysta z aluzji do rzeczywistości społecznej i dlatego zawiera element performansu. Współczesne performanse polityczne powstają „tu i teraz”, tworząc teatr z elementami zmysłowości, rozrywkowości i obojętności wobec dobrego smaku. Powstający teatr polityczny trzeba zatem zdefiniować jako proces, a nie rezultat. Jako moment tworzenia i działania nierozerwalnie złączony z energią. Współczesne „centrum energetyczne” sztuki to wytwarzanie zdarzeń, wyjątkowych stanów i chwil. Zaliczyć do nich można chociażby wspomniany happening w Kozłówce, który jako przejaw teatralizacji zdarza się „tu i teraz”, jest przerwaniem codzienności, po prostu się dzieje. H.T. Lehman określa to mianem „luki w ciągłości”. Jednocześnie nie nazywa happeningu politycznego teatrem, raczej sposobem na kwestionowanie i doświadczanie siebie ${ }^{14}$.

Niektórzy badacze w takich teatralizacjach widzą pewne „lekarstwo” na współczesność. Tłumacząc działania Palikota, można przytoczyć Sloterdijka, który we współczesności dostrzega zakłócenie witalności człowieka. Można ją odzyskać dzięki optymistycznemu spojrzeniu na zdarzenia, uzewnętrznieniu ekspresji ${ }^{15}$. Niezbędne są więc dla rozwoju kultury i polityki burzliwe wzloty i upadki, swego rodzaju dramatyczność i teatralność, która będąc wspólnym mianownikiem społecznych ekspresji życia, może być zbawienna dla witalności społeczeństwa. Sloterdijk nawołuje zatem do swego rodzaju przyjęcia postawy otwartej i przychylnej zjawiskom, których charakter możemy określić jako „ekspresywny i teatralny." Nie chodzi mu tylko o rodzaj dystansu wobec nich, ale o przyjęcie roli pozytywnie nastawionego wobec rzeczywistości uczestnika tych zdarzeń.

Bierność i nieautentyczność stały się domeną nowoczesności, a narzuciła je nam cywilizacja i upowszechnienie się mediów. Jolanta Brach-Czaina przyczyn takiej postawy upatruje przede wszystkim w globalizacji, zagubieniu człowieka we współ-

\footnotetext{
12 H.T. Lehman, Teatr postdramatyczny, Kraków 2009, s. 86.

13 Ibidem, s. 87.

${ }^{14}$ Ibidem, s. 166.

15 P. Sloterdijk, op. cit., s. 137.
} 
czesnej przestrzeni miejskiej i nieumiejętności radzenia sobie z ograniczeniem bezpośredniej obecności drugiego człowieka. Owa bezpośrednia obecność została bowiem sprowadzona do odbioru komunikatu medialnego. Realnym zagrożeniem jest więc telewizja, która sprawiła, że człowiek zmuszony jest do przedstawiania siebie (prezentacji). Współczesny świat staje się obrazem a człowiek nowoczesny stał się obserwatorem bytu. Jako obserwator bytu nie jest już jego odbiorcą. I jak słusznie to ujął w poniższym cytacie Paweł Hudzik, jako obserwator bytu nie jest już jego odbiorcą:

dla niego wszystko w świecie musi zmienić się w przeżycie — w „pogląd”, „ogląd”, „przedstawienie”. Oderwany od więzi z bytem, tęskni, odczuwa potrzebę poglądu na świat, w tym celu „sam przenosi się na scenę, tzn. w otwarty krąg tego, co przedstawiane, powszechnie i publicznie" 16 .

Przywołując Heideggera, Jan Paweł Hudzik stwierdza, że człowiek sam czyni z siebie scenę, na której musi się przedstawiać, być obrazem. Charakterystyczne dla nowoczesnego życia stało się więc ciągłe stawanie się innym, balansowanie między tym samym a podobnym. Ale także balansowanie między różnymi sposobami doświadczania obecności.

Media zarzuciły tę grę ,aktorom” i odbiorcom. Współcześni aktorzy medialni muszą wyróżniać się specyficznym rodzajem skupienia, które pozwoli im na spontaniczne reagowanie i szybkie, zdecydowane działania.

Z jednej strony w politycznych inscenizacjach obserwujemy Palikota, który używając elementów teatralnych, absorbuje naszą uwagę w sposób mniej lub bardziej wyrafinowany. $Z$ drugiej zaś mamy do czynienia z takimi praktykami politycznymi, które moim zdaniem w przyszłości mogą stanowić o politycznym „być albo nie być”. Ważne staje się w nich ,prawdziwe bycie sobą" rozumiane jako samoujawnienie się i pozbycie się zahamowań. Współczesne aktorstwo teatralne i polityczne wymaga przede wszystkim umiejętności wydobycia swojej naturalności, indywidualnego sposobu bycia. „Wydobycie osobistej temperatury”17 łączyć należy z ciężką pracą nad sobą, z kwestią przepracowania swoich emocji i analizy życiowych zdarzeń. Takie podejście do aktorstwa propagowali między innymi Stanisławski i Grotowski. A jego skondensowaną odmianę stanowi sztuka improwizacji, która chyba najwierniej oddaje codzienne życie, a zwłaszcza sposób naszego reagowania, najbardziej widoczny w kontakcie z drugim człowiekiem. Pisząc więc o „prawdziwym byciu”, chodzi mi o „bycie” politykiem, które wiąże się ze sceniczną obecnością, energią, organicznością, świadomością występowania i spontanicznością, bo one nadają występowi jakość. Cechy te charakteryzują praktyki polityczne Roberta Biedronia. W wyniku ich działania dochodzi bowiem do ujawnienia „prawdziwego ja" posła. Przykładem może tu być publiczne przyznanie się do homoseksualizmu,

16 J.P. Hudzik, Niepewność realnego. O nowoczesnym życiu w świecie iluzji, [w:] Estetyka realności, red. M. Ostrowski, Kraków 2005, s. 44.

17 Sekretna sztuka aktora, red. E. Barba, N. Savarese, Wrocław 2005. 
które było dla niego nie tylko walką z sobą i własnymi zahamowaniami, lecz także zmierzeniem się z opinią publiczną. Okazało się to dość bolesnym doświadczeniem, zwłaszcza gdy przypomnimy sobie reakcję większości posłów, którzy na słowa Biedronia „poniżej pasa” zareagowali na sali sejmowej głośnym śmiechem. Sytuacja ta miała także swój wymiar performatywny. Biedroń, występując na mównicy sejmowej przed poselskim audytorium, wcielił się w polityka, to zaś intensyfikuje i wyostrza znaczenie tego, co i jak mówi. Reakcja publiczności świadczy o tym, że pomieszane zostały odgrywane przez niego role. To, co prywatne i intymne, staje się wydarzeniem o statusie publicznym.

Energia, spontaniczność, bycie sobą i organiczność wpływają zarówno na kształt aktorstwa politycznego, jak i na jakość występu, i należy je traktować jako zintensyfikowane „działania na scenie”.

Różnica między „działać” a „przedstawiać” tkwi nie w rozróżnieniu „teatr” a „prawdziwe życie”, lecz w nastawieniu - możemy czynić różne rzeczy bezmyślnie, ale gdy myślimy o nich, wprowadza to czynnik świadomości, który nadaje jakość występowi. Podobnie uważa Schechner, twierdząc, że im człowiek jest bardziej świadomy, tym bardziej kreuje swe zachowania na użytek tych, którzy go obserwują. I tym bardziej są one performatywne ${ }^{18}$.

Jakość występu jest więc niczym innym niż zintensyfikowanym działaniem aktora na scenie - to, co uznajemy za codzienne, normalne zachowanie, na scenie znacznie się wzmacnia. Aby osiągnąć ową intensyfikację, aktor może posłużyć się wieloma środkami artystycznymi, ale nie zaistnieje na scenie bez energii, charyzmy, siły czy talentu, które są punktem wyjścia do dalszego działania.

Energia jest najważniejszym elementem gry aktorskiej. Aktor pozbawiony energii nie jest w stanie wykreować postaci. Energia oraz związane z nią sceniczne „bycie" będą jednym z głównych narzędzi użytych do moich rozważań nad teatralizacją zachowań politycznych Roberta Biedronia. Przy pierwszym zetknięciu z zachowaniem polityka trudno zaryzykować określenie ,teatralne”, ze względu na naturalny i niewymuszony sposób bycia, pozbawiony zachowań manierycznych. Uciekamy więc od teatralnych skojarzeń, które w potocznym rozumieniu niosą wyniosłą formę i „koturnowość”. Chciałabym jednak przypomnieć i jeszcze raz podkreślić, że takie myślenie jest dalekie od współczesnych kwalifikacji tego, co teatralne jest, a co nie.

Eugenio Barba powiedział, że „niektórzy aktorzy wschodni i zachodni dysponują pewną jakością obecności, która natychmiast uderza widza i przykuwa jego uwagę"19. Moim zdaniem taką właśnie jakość obecności ma Robert Biedroń. Używa się też innego określenia na to zjawisko — bios, czyli życie sceniczne.

Barba dzieli techniki aktorskie na codzienne i pozacodzienne. W kulturze Zachodu dystans je dzielący jest mało wyraźny, w przeciwieństwie do Indii — tu różnica między tymi dwiema technikami jest oczywista i ma nawet swoją termi-

\footnotetext{
${ }^{18}$ R. Schechner, Performatyka. Wstęp, przeł. T. Kubikowski, Wrocław 2006.

19 Sekretna sztuka aktora, s. 8.
} 
nologię: lakodharmi i natjadharmi. W technikach codziennych maksymalny rezultat osiąga się kosztem małego nakładu energii. Celem tych technik jest komunikacja, z kolei celem technik pozacodziennych — informacja, czyli wstawienie ciała $\mathrm{w}$ odpowiednią formę ${ }^{20}$.

Energii nie rozumiem tu jako szybkiego ruchu czy przesadnej żywiołowości i zaangażowania ciała. Kluczowe w zrozumieniu życia aktora jest zrozumienie zasady, że energia nie zawsze wiąże się z ruchem w przestrzeni. Nie należy także łączyć energii z gwałtownością i krzykiem. Jest ona „osobistą temperaturą i intensywnością", którą aktor powinien w sobie pobudzać i modelować. Energia według Barby nie ma płci, nie jest ani męska, ani żeńska, istnieje jako typowa, charakterystyczna dla danego człowieka. A zadaniem aktora jest odkrycie jej naturalnych skłonności i pielęgnowanie jej wyjątkowości.

Takiemu rozumieniu politycznego „aktorstwa” bliska jest metoda Stanisławskiego, a konkretniej to, co nazwał „najzwyklejszym ludzkim stanem”: ciało-umysł organiczny. Owa organiczność zazwyczaj ujawnia się w ciele, które reaguje naturalnie, a nie w sposób wewnętrznie sprzeczny i jałowy, unikając tym samym działań zbędnych $^{21}$. Cóż z tego, skoro ten najzwyklejszy stan ludzki znika, gdy wchodzi się na scenę czy przystępuje do występu. Wówczas nasze ciało zaczyna wytwarzać rozmaite zachowania niezdarne, niespójne, często zaprzecza sobie. Jest jednak rada, aby tę organiczność odtworzyć: to rzeczywiste życie ludzkie, a do tego praca, technika i studiowanie. Istotą systemu Stanisławskiego jest nie tylko organiczność, swoboda bycia na scenie, pewność swoich działań, gotowość do improwizacji, ale przede wszystkim suma życiowych doświadczeń i emocji, które zostały przepracowane i przywołane na scenie. Należy pamiętać, że współcześnie termin „organiczność” zastępuje wcześniejszą naturalność (nie wiążąc się w żaden sposób z naturalizmem) i oznacza teraz wpływ na widza.

Oczywiście aby móc orzec, że Robert Biedroń posiadł energię sceniczną, należy poddać jego zachowanie obserwacji, która stanowi podstawę w mojej metodologii badań. Analiza materiałów dostępnych w polskich mediach pozwala zobaczyć zachowania polityczne Roberta Biedronia jako wręcz typowo teatralne i skoncentrowane wokół zagadnień gry aktorskiej i jej wyznaczników, głęboko zakorzenionych w aktorskiej tradycji Eugenia Barby czy Konstantina S. Stanisławskiego. Biedroń jest autentyczny, a odwaga, którą ma, powoduje, że mamy do czynienia ze świadomym byciem scenicznym, a nie odtwarzaniem. Występuje, ponieważ chce powiedzieć nam o rzeczach ważnych dla siebie i dla współczesnej polityki.

Wszystko to przekłada się na jego prezentacje: są prawdziwe i naturalne, ponieważ aktor dokonał wcześniej publicznego „zdjęcia maski”. Odkrył przed publicznością swoją najdelikatniejszą, najbardziej wstydliwą stronę. To doświadczenie uczyniło jego wystąpienia silnymi i odważnymi, pozbawionymi zmanie-

20 Ibidem.

${ }^{21}$ F. Ruffini, System Stanisławskiego, [w:] Sekretna sztuka aktora, s. 99. 
rowanych i sztucznie wykreowanych zachowań. Dokonał tego, czego oczekiwał od aktora Jerzy Grotowski. Samoujawnienie, pozbycie się własnych zahamowań i uwolnienie „możliwości swojej osobowości” traktował nie tylko jako klucz do prawdy o człowieku, lecz także upatrywał w ich realizacji podstaw współczesnego aktorstwa. Czy miał rację? Odpowiedzią niech będzie rozwój i rosnąca popularność technik improwizacyjnych, polegających na „odsłanianiu prawdziwego ja”, które stały się fundamentem teatru improwizacyjnego.

Gdzie jest jednak miejsce w opisanych praktykach politycznych na uczestnictwo? Jak należy je definiować w tym przypadku? Problem leży tutaj w uczestnictwie zarówno aktora politycznego w wydarzeniu, jak i samego odbiorcy. Czy w obydwu przypadkach możemy zatem mówić o aktywnym uczestnictwie, rozumianym jako naturalna chęć do współdziałania i doświadczania obecności drugiej osoby?

W ten sposób rozumie je Jolanta Brach-Czaina. Wychodząc od porównania spotkania towarzyskiego ze sztuką teatralną, uważa, że uczestnictwo buduje tkankę zdarzenia.

Należy więc po pierwsze — odkrywać i manifestować siebie: być sobą. Należy być czynnym uczestnikiem spotkania: zatem podejmować działania i wykonywać czynności budujące bezpośrednio tkankę zdarzenia. Należy wreszcie być współobecnym: poddawać się czynnej obecności innych i samemu na innych oddziaływać, podtrzymywać wieloraką komunikację osób, zaakceptować czynną obecność i współdziałanie grupy ${ }^{22}$.

Można uznać, że dla Brach-Czainy uczestnictwo w zdarzeniu politycznym to obustronne doświadczenie bezpośredniej obecności zarówno polityka, jak i odbiorcy.

Kamera i odbiornik telewizyjny sprawiły, że bezpośrednie spotkanie — istota teatru - zostało zastąpione uczestnictwem w generowaniu komunikatu politycznego - w przypadku polityka i uczestnictwem w odbiorze treści medialnych w przypadku odbiorcy. $Z$ jednej strony ograniczamy nasze uczestnictwo w kulturze do konsumowania treści medialnych (komunikatów politycznych), a z drugiej szukamy prawdziwego człowieka - nie tylko polityka ${ }^{23}$.

$\mathrm{W}$ przeciwieństwie do aktora politycznego odbiorca pozbawiony jest bezpośredniego uczestnictwa w sytuacji „tu i teraz”, jest skazany jedynie na samotne doświadczenie bycia obserwatorem przetworzonej rzeczywistości. Tym samym może zrodzić się w nim poczucie, że nie doświadcza „naprawdę”. Jego uczestnictwo jest ograniczone, bo buduje jedynie wspólnotę odbiorców medialnych, tym samym poddane zostaje ono w wątpliwość. Przez brak bezpośredniego uczestnictwa w wydarzeniu, w „dzianiu się”, pozostaje zawieszony między tym, co jest rzeczywiste, i tym, co jest reprezentacją rzeczywistości. Nie może bowiem, przez swoją nieobecność w zdarzeniu, zweryfikować jego autentyczności. Coraz większe

22 J. Brach-Czaina, O nie graniu roli, „Dialog” 2008, nr 8, s. 110.

${ }^{23}$ W. Godzic, Telewizja i jej gatunki. Po Wielkim Bracie, Kraków 2014. 
znacznie w przekazach politycznych będzie miał taki sposób przedstawiania, który skupiać się będzie na tym, co autentyczne. Coraz silniejsza także stanie się potrzeba zaistnienia w komunikacie elementów, które jak najskuteczniej zbliżą nas do rzeczywistości. Jest to swego rodzaju remedium na współczesne uczestnictwo polityka w kulturze. Pozwala zarówno aktorowi, jak i odbiorcy doświadczyć rzeczywistości.

Cóż zatem zostało z tego klasycznego myślenia o polityce, której prezentacje zakładały dbałość o słowo, powagę i tradycyjną formę przekazu? Nowoczesność wymusiła na aktorze politycznym taką samą zmianę stosowanych środków w przekazie illokucyjnym i w stosowaniu środków ekspresji jak w wypadku aktora teatralnego.

Bezpośrednie spotkanie nie może zostać zastąpione anonimowym obcowaniem z elektronicznym obrazem, a poruszenie widza sprowadzone do generowania lęku, który, jak zauważył Zygmunt Bauman, cechuje człowieka popkultury ${ }^{24}$. Wspominana nieautentyczność i bierność są reakcją na ten lęk i należy je odnieść zarówno do odbiorcy medialnego, jak i do aktora. Czy obecność elementów „odkrywania prawdy" we współczesnych komunikatach politycznych może być wyjściem z tego impasu?

Tylko podczas bezpośredniego spotkania $\mathrm{z}$ drugim człowiekiem jesteśmy w stanie doświadczyć jego obecności. W wypadku dominacji medium wydaje się to niemożliwe. Inscenizacja i widowiskowo, czy ogólnie działania performatywne, zdają się pomagać politykom w osiąganiu takiego efektu, a umiejętne ich wykorzystanie może przynieść nie tylko wyborczy sukces, lecz także dostarczyć odbiorcy swego rodzaju doświadczenia obecności, rzeczywistości, namacalności.

Rezygnacja z konwencji i sztuczności na rzecz autentyczności i normalności to zdaniem Wiesława Godzica reakcja na współczesne lęki człowieka. Lęki, które potrafimy oswoić. Bronimy się przed nimi, dokonując medialnych „obnażeń”. Ponadto telewizja stała się zdominowana przez dyskurs rozrywkowy i jest on zauważalny w łzawych i dramatycznych opowieściach, relacjach docu-soap i reality show ${ }^{25}$. Beata Guczalska pisze o funkcji, jaką pełnią ekrany i telewizja w teatrze, ich wpływie na aktora, co przekłada się na ogólny model funkcjonujący w przypadku aktorstwa medialnego (w tym politycznego):

Ekrany i telewizja stanowią specyficzną konkurencję, mobilizują do osiągnięcia takiego stanu scenicznej obecności, który pozwoli odczuć fenomen żywej obecności w przestrzeni teatru. Owa zintensyfikowana obecność nie polega na sięganiu po atrakcyjne efekty — przeciwnie — przyciąga raczej koncentracja i intensywność niezapośredniczonego bycia, kwestionująca świadectwo przetworzonego cyfrowo obrazu ${ }^{26}$.

Pytanie, czy jest to wyłącznie tęsknota za żywym uczestnictwem i autentycznością drugiego człowieka? Czy może bezwzględny dyktat medialnej machiny?

\footnotetext{
${ }^{24}$ Z. Bauman, Bauman o popkulturze. Wypisy, Warszawa 2008, s. 261.

${ }^{25}$ W. Godzic, op. cit., s. 232.

${ }^{26}$ B. Guczalska, Aktorstwo polskie. Generacje, Kraków 2014, s. 438.
} 
Z całą pewnością opisane tu praktyki polityczne biorą górę nad uprawianą dotąd tradycyjnie polityką. Wymaga tego przede wszystkim współczesna kultura i dominująca w odbiorcach chęć przeżycia jak największej ilości bodźców, bo jak pisze Wojciech Burszta: „Liczy się chwila obecna, jej przemożny dyktat (zawsze zdarzy się coś ciekawego i/lub okrutnego)..."27. Za sprawą Roberta Biedronia jesteśmy świadkami odmiany polskiej sceny politycznej, która coraz bardziej przypomina scenę teatralną, przenosząc zdarzenia polityczne w „sferę wirtualnej konstrukcji preferowanych obrazów świata"28. Oczywiście Robert Biedroń nie jest w Polsce protoplastą takich nietuzinkowych zachowań, znacznie wcześniej pojawił się Janusz Palikot. Czyżby jako pierwszy wyczuł zmiany, którym polityka, jako jedna z dziedzin kultury, też zaczyna podlegać? Niewątpliwie tak. Rola polityka już nie sprowadza się do dodawania sobie powagi i dostojeństwa, jak to było w przypadku Józefa Cyrankiewicza czy Gabriela Narutowicza. Dzisiejsi politycy raczej tę powagę chcą z siebie zdjąć, prezentując publiczności swoją ludzką, naturalną, dowcipną i gotową do stawienia czoła wyzwaniom postawę.

Przedstawione przeze mnie przykłady pokazują, że chcąc badać współczesne praktyki polityczne, należy sięgnąc po narzędzia dostępne kilku dziedzinom: teatrologii, antropologii, kulturoznawstwa, historii, a w niektórych przypadkach i marketingu politycznego. Dlatego tak istotne było wprowadzenie tu terminologii z dziedziny performatyki i teatrologii, gdyż to za pomocą narzędzi przez nie wykorzystywanych możemy poddać analizie konkretne zachowania polityczne, które zyskują przez to głębszy wymiar.

Czy zatem działania wymienionych polityków są inscenizacją rozumianą jako współgranie teatralności i performatywności? Tak. Są teatralne, ponieważ zawierają widoczne i znaczące środki sceniczne. Są performatywne, ponieważ realizują działania, ale też żywo działają na nas (już nie jedynie odbiorców politycznych komunikatów), uczestników reagujących na obecność polityka.

\section{Contribution on the study performance of contemporary political practices. Analysis of selected examples}

\section{Abstract}

According to Jon McKenzi almost every aspect of human life today is driven by a pressure to perform. It is, therefore, understandable, why both past and current political practices are analysed using the tools offered by performativity. Performativity, however, has never been considered a ho-

27 W. Burszta, W objęciach postkultury politycznej, przedmowa, [w:] Politrozrywka i popperswazja, red. T. Olczyk, Warszawa 2009, s. 12.

${ }^{28}$ Ibidem, s. 16. 
mogeneous field. This is why I will present the reasons I decided to choose the current of it that exposes the theatrical genealogy of contemporary cultural and organisational performances (theatricality of politics was discussed by Bertolt Brecht). I truly believe that research tools offered by this current will create an optimal opportunity to describe strategies presently used in both politics and the political (which is Chantal Moufee's conception). It is my intention to apply the initial theoretical concepts to particular examples of political practices in Poland.

Keywords: performance studies, theatre, politics

\section{Bibliografia}

Bauman Z., Bauman o popkulturze. Wypisy, Warszawa 2008.

Bourdieu P., O telewizji. Panowanie dziennikarstwa, przeł. K. Sztander-Sztanderska, A. Ziółkowska, Warszawa 2009.

Brach-Czaina J., O nie graniu roli, „Dialog” 2008, nr 8.

Burszta W., W objęciach postkultury politycznej, przedmowa, [w:] Politrozrywka i popperswazja, red. T. Olczyk, Warszawa 2009.

Fischer-Lichte E., Estetyka performatywności, przeł. M. Borowski, M. Sugiera, Kraków 2008.

Godzic W., Telewizja i jej gatunki. Po Wielkim Bracie, Kraków 2014.

Guczalska B., Aktorstwo polskie. Generacje, Kraków 2014.

Hübner Z., Polityka i teatr, Warszawa 2009.

Hudzik J.P., Niepewność realnego: O nowoczesnym życiu w świecie iluzji, [w:] Estetyka realności, red. M. Ostrowski, Kraków 2005.

Kosiński D., Teatra polskie. Rok katastrofy, Warszawa-Kraków 2013.

Kosiński D., Tratwa i cuma, „Didaskalia” 2007, nr 77.

Kubikowski T., Wstęp, [w:] J. McKenzie, ,Performuj albo...” Od dyscypliny do performansu, przeł. T. Kubikowski, Kraków 2011.

Lehman H.T., Teatr postdramatyczny, Kraków 2009.

Pavis P., Stownik terminów teatralnych, przeł. S. Świontek, Wrocław 2002.

Pavis P., Wspótczesna inscenizacja, przeł. P. Olkusz, Warszawa 2011.

Raszewski Z., Teatr w'świecie widowisk, Warszawa 1991.

Ruffini F., System Stanisławskiego, [w:] Sekretna sztuka aktora. Stownik antropologów teatru, red. E. Barba, N. Savarese, Wrocław 2005.

Schechner R., Performatyka. Wstęp, przeł. T. Kubikowski, Wrocław 2006.

Sekretna sztuka aktora. Stownik antropologii teatru, red. E. Barba, N. Savarese, Wrocław 2005.

Sloterdijk P., Krytyka cynicznego rozumu, przeł. P. Dehnel, Wrocław 2008. 